\title{
Motesanib inhibits Kit mutations associated with gastrointestinal stromal tumors
}

\author{
Sean Caenepeel1', Lisa Renshaw-Gegg², Angelo Baher¹, Tammy L Bush¹, Will Baron², Todd Juan², Raffi Manoukian³, \\ Andrew S Tasker ${ }^{4}$, Anthony Polverino 5 and Paul E Hughes*1
}

\begin{abstract}
Background: Activating mutations in Kit receptor tyrosine kinase or the related platelet-derived growth factor receptor (PDGFR) play an important role in the pathogenesis of gastrointestinal stromal tumors (GIST).

Methods: This study investigated the activity of motesanib, an inhibitor of vascular endothelial growth factor receptors (VEGFR) 1, 2, and 3; PDGFR; and Kit, against primary activating Kit mutants and mutants associated with secondary resistance to imatinib. Single- and double-mutant isoforms of Kit were evaluated for their sensitivity to motesanib or imatinib in autophosphorylation assays and in Ba/F3 cell proliferation assays.

Results: Motesanib inhibited Kit autophosphorylation in $\mathrm{CHO}$ cell lines expressing primary activating mutations in exon 9 (AYins503-504, IC $C_{50}=18 \mathrm{nM}$ ) and exon 11 (V560 D, IC $C_{50}=5 \mathrm{nM} ; \Delta 552-559, I C_{50}=1 \mathrm{nM}$ ). Motesanib also demonstrated activity against kinase domain mutations conferring imatinib resistance $\left(V 560 D / N 654 \mathrm{~A}, I C_{50}=77 \mathrm{nM}\right.$; $\left.\mathrm{V} 560 \mathrm{D} / \mathrm{T670I}, \mathrm{IC} \mathrm{C}_{50}=277 \mathrm{nM} ; \mathrm{Y} 823 \mathrm{D}, \mathrm{IC} \mathrm{I}_{50}=64 \mathrm{nM}\right)$ but failed to inhibit the imatinib-resistant D816V mutant $\left(\mathrm{IC}_{50}>3000\right.$ nM). Motesanib suppressed the proliferation of Ba/F3 cells expressing Kit mutants with $\mathrm{IC}_{50}$ values in good agreement with those observed in the autophosphorylation assays.
\end{abstract}

Conclusions: In conclusion, our data suggest that motesanib possesses inhibitory activity against primary Kit mutations and some imatinib-resistant secondary mutations.

\section{Background}

Approximately $85 \%$ to $90 \%$ of all cases of gastrointestinal stromal tumors (GIST) are associated with gain-of-function mutations in the gene KIT [1-4]. A further $5 \%$ to $10 \%$ of cases of GIST are associated with activating mutations in the platelet-derived growth factor receptor alpha (PDGFR $\alpha$ ) gene $[1,4,5]$. Activating Kit mutations in GIST occur principally in the extracellular domain, the juxtamembrane domain (which regulates receptor dimerization), kinase domain I, and kinase domain II (or activation loop) [1]. Imatinib, a small-molecule inhibitor of Kit and PDGFR $\alpha$, represents an effective first-line therapy option for patients with advanced GIST [6]. Imatinib is a potent inhibitor of wild-type Kit and juxtamembrane domain Kit mutants, while Kit activation loop mutants are resistant [1,7]. Secondary imatinib resistance is most

* Correspondence: phughes@amgen.com

1 Department of Oncology Research, Amgen Inc., One Amgen Center Drive, Thousand Oaks, CA, 91320-1799, USA

Full list of author information is available at the end of the article commonly associated with the acquisition of a secondary mutation in Kit (either in the kinase domain I or the activation loop) or in PDGFR $\alpha$ [8].

Motesanib is an orally administered small-molecule antagonist of vascular endothelial growth factor receptors (VEGFR) 1, 2, and 3; PDGFR and Kit [9,10]. In clinical studies, motesanib has shown encouraging efficacy in the treatment of patients with advanced solid tumors [1013]. In biochemical assays, motesanib potently inhibits the activity of both Kit (50\% inhibitory concentration $\left.\left[\mathrm{IC}_{50}\right]=8 \mathrm{nM}\right)$ and PDGFR $\left(\mathrm{IC}_{50}=84 \mathrm{nM}\right)$ [9], suggesting that it may have direct antitumor activity in GIST $[14,15]$. The aim of this study was to characterize the ability of motesanib to inhibit the activity of wild-type Kit in vitro and in vivo, and to investigate differences in the potency of motesanib and imatinib against clinically important primary activating Kit mutants and mutants associated with secondary imatinib resistance. The results suggest that motesanib has inhibitory activity against primary Kit mutations and some imatinib-resistant secondary mutations.

() 2010 Caenepeel et al; licensee BioMed Central Ltd. This is an Open Access article distributed under the terms of the Creative ComBH Wed Central mons Attribution License (http://creativecommons.org/licenses/by/2.0), which permits unrestricted use, distribution, and reproduction in any medium, provided the original work is properly cited. 


\section{Methods Reagents}

Unless specified otherwise all reagents were purchased from Sigma Aldrich; all cell culture reagents were purchased from Invitrogen (Carlsbad, CA).

\section{In Vivo Hair Depigmentation Assay}

Female C57B6 mice (6 to 8 weeks old; 20 to $30 \mathrm{~g}$; Charles River Laboratories, Wilmington, MA) were anesthetized, and an area of skin $2 \times 2 \mathrm{~cm}$ on the right flank was depilated. Oral administration of either $75 \mathrm{mg} / \mathrm{kg}$ motesanib (Amgen Inc., Thousand Oaks, CA) or vehicle (water, $\mathrm{pH}$ 2.5) was initiated on the same day as depilation and continued for 21 days. On day 21, photographs were taken for assessment of hair depigmentation. The same patch of skin was depilated again on day 28 , and photographs for assessment of depigmentation were taken on day 35. All animal experimental procedures were conducted in accordance with the guidelines of the Amgen Animal Care and Use Committee and the Association for Assessment and Accreditation of Laboratory Animal Care standards.

\section{Preparation of Wild-Type and Mutant KIT Constructs}

KIT mutants (Table 1) were identified from published reports [8] and generated using PCR-based site-directed mutagenesis. PCR products were cloned into the pcDNA3.1+ hygro vector or the pDSR $\alpha 22$ vector (Amgen Inc), gel purified, and then ligated with a common $5^{\prime}$ fragment of human wild-type KIT to yield full-length, mutant constructs in pcDNA3.1+ hygro or pDSR $\alpha 22$ expression vectors.

\section{Stable Transfection of $\mathrm{CHO}$ and Ba/F3 Cells With Wild-Type and Mutant KIT}

AM-1/D Chinese Hamster Ovary (CHO) cells (Amgen Inc.) were maintained under standard conditions. Cells were transfected with wild-type or mutant KIT using Lipofectamine2000 and Opti-MEM (Invitrogen) follow- ing the manufacturer's instructions. Four days after transfection, cells were transferred into selection medium: Gibco DMEM High Glucose with 10\% FBS plus $300 \mu \mathrm{g} /$ $\mathrm{mL}$ hygromycin (Roche Applied Sciences, Indianapolis, IN) for cells transfected with pcDNA3.1+ hygro; DMEM High Glucose with $10 \%$ dialyzed FBS for cells transfected with pDSR $\alpha 22$. Stably transfected $\mathrm{CHO}$ cells were selected 2 weeks later and maintained as described above.

Interleukin 3 (IL-3)-dependent Ba/F3 cells were maintained under standard conditions including $3 \mathrm{ng} / \mathrm{mL}$ murine IL-3 (Cat \# PMC0035; Invitrogen/BioSource). Cells were transfected with wild-type or mutant KIT in the pDSRa22 expression vector along with linearized pcDNA Neo using the Nucleofector Kit $V$ and a Nucleoporator (Lonza; Cologne, Germany) following the manufacturer's instructions. Two to 3 days post transfection, cells were transferred into selection medium (supplemented RPMI medium plus $750 \mu \mathrm{g} / \mathrm{mL}$ G418). Stably transfected $\mathrm{Ba} / \mathrm{F} 3$ cells were maintained in supplemented RPMI medium plus $3 \mathrm{ng} / \mathrm{mL}$ murine IL-3.

Fluorescence activated cell sorting (FACS) was utilized to isolate pools of $\mathrm{CHO}$ and $\mathrm{Ba} / \mathrm{F} 3$ cells stably expressing wild-type and mutant $K I T$ variants. FACS was performed on a FACS Aria cell sorter (BD Biosciences San Jose, CA), under sterile conditions using $488 \mathrm{~nm}$ laser excitation. KIT transfected cells were labeled with the anti-Kit monoclonal antibody SR1 (prepared at Amgen Inc.; data on file) followed by incubation with FITC-labeled secondary anti-mouse IgG antibody (SouthernBiotech, Birmingham, AL). Cells were then resuspended in Dulbecco's phosphate-buffered saline with $0.5 \%$ bovine serum albumin at a final concentration of $1 \times 10^{6}$ cells per $\mathrm{mL}$ to ensure a constant and viable sorting rate of 5000 cells/sec. Cells transfected with vector control were used to adjust the baseline instrument settings. Forward and side scatter gating enabled the exclusion of dead cells and debris. The top $10 \%$ to $15 \%$ of Kit-positive cells within the overall transfected cell population were then isolated to ensure collection of high-expressing cells. Cells were

Table 1: Clinically Relevant KIT Mutations

\begin{tabular}{lcc}
\hline KIT Genotype & Mutation Type & Domain \\
\hline Primary activating mutations & Deletion & Juxtamembrane domain \\
S552-559 & Single mutation & Juxtamembrane domain \\
V560D & Insertion & Extracellular domain \\
AYins503-504 & & Activation loop \\
Secondary imatinib-refractory mutations & Single mutation & Activation loop \\
D816V & Single mutation & Juxtamembrane domain/kinase domain I \\
Y823D & Double mutation & Juxtamembrane domain/kinase domain I \\
V560D/V654A & Double mutation &
\end{tabular}


sorted directly into $15 \mathrm{~mL}$ conical tubes containing the appropriate growth media. Cell pools were then cultured and maintained under the respective selection conditions, and were reanalyzed for Kit expression prior to characterization of Kit autophosphorylation.

\section{Cell-Based Kit Autophosphorylation Assay}

CHO cells stably transfected with wild-type or mutant isoforms of KIT were seeded in a 96-well tissue culture plate at a density of $2 \times 10^{4}$ cells per well. For stem cell factor (SCF) characterization experiments, cells were stimulated with serial dilutions of SCF for varying times. To determine $\mathrm{IC}_{50}$ values, the cells were treated for 2 hours with single 10-fold serial dilutions of motesanib or imatinib starting at $3 \mu \mathrm{M}$. Cell lines transfected with wild-type KIT were stimulated for 10 minutes with 100 $\mathrm{ng} / \mathrm{mL}$ SCF following treatment with motesanib or imatinib. Cell lines transfected with activating KIT mutants were not stimulated with $\mathrm{SCF}$ in $\mathrm{IC}_{50}$ experiments. Cells were washed with phosphate-buffered saline and lysed in RIPA buffer (50 mM Tris, pH 7; $150 \mathrm{mM} \mathrm{NaCl,} \mathrm{1 \%} \mathrm{Igepal,}$ $0.5 \%$ sodium deoxycholate, $0.1 \%$ SDS, $300 \mu \mathrm{M}$ activated sodium vanadate, $1 \times$ protease inhibitor cocktail) for 30 minutes at $4^{\circ} \mathrm{C}$ with shaking. Cell lysates were added to a 96-well DELFIA microplate (PerkinElmer Inc.) coated with anti-Kit antibody $(1 \mu \mathrm{g}$ per well; AF332, R\&D Systems, Inc.; Minneapolis, MN) and incubated for 2 hours. Lysates were then removed and the plate was washed 3 times with DELFIA wash buffer (PerkinElmer Inc.). Recombinant anti-phosphotyrosine antibody 4G10 (Cat. \# 05-777; Upstate/Millipore, Billerica, MA) was added to each well $(0.1 \mu \mathrm{g}$ per well) and incubated at room temperature for 1 hour. The plate was then washed 3 times with DELFIA wash buffer before $0.01 \mu \mathrm{g}$ of Eu-N1-labeled anti-mouse antibody (Cat. \# AD0124, PerkinElmer Inc.) was added to each well. The plate was again incubated at room temperature for 1 hour and then washed 3 times with DELFIA wash buffer before the signal was detected by adding DELFIA enhancement buffer (PerkinElmer Inc.) to each well. Luminescence was measured using a Victor Model 1420 multilabel counter (PerkinElmer Inc.). Kit autophosphorylation at each motesanib or imatinib concentration was expressed as a percentage of the vehicle control (0.2\% DMSO).

\section{Ba/F3 Functional Viability Assay}

The ability of Kit mutants to act as survival factors was assessed in Kit-dependent Ba/F3 cells. Ba/F3 cells stably transfected with various $K I T$ mutants were seeded in a 96-well tissue culture plate at a density of $5 \times 10^{3}$ cells per well. To determine $\mathrm{IC}_{50}$ values, cells were treated for 24 hours with single 10 -fold serial dilutions of motesanib or imatinib starting at $3 \mu \mathrm{M}(0.1 \mu \mathrm{M}$ for motesanib-treated V560 D and $\Delta 552-559$ Kit mutants). Cell viability was assessed by measuring the level of adenosine triphosphate using ATPlite assays (PerkinElmer Life Sciences, Boston, MA). Reconstituted ATPLite 1-step solution was added to each well followed by incubation with shaking for 2 minutes. The plate was read on a Victor Model 1420 multilabel counter (PerkinElmer Inc.) under the luminescence setting. Viability at each motesanib or imatinib concentration was expressed as a percentage of the vehicle control (0.2\% DMSO).

\section{Results}

\section{In Vitro Inhibition of Wild-Type Kit by Motesanib}

Motesanib potently inhibited SCF-induced autophosphorylation of Kit in $\mathrm{CHO}$ cells stably transfected with the wild-type $K I T$ gene $\left(\mathrm{IC}_{50}=36 \mathrm{nM}\right)$. In comparison, imatinib inhibited wild-type Kit with an $\mathrm{IC}_{50}$ of $165 \mathrm{nM}$.

\section{Inhibition of Wild-Type Kit Activity in Mice by Motesanib}

Hair depigmentation was used as a surrogate marker to assess the ability of motesanib to inhibit Kit activity in vivo [16]. Following depilation, female C57B6 mice were administered either $75 \mathrm{mg} / \mathrm{kg}$ motesanib $(\mathrm{n}=8)$ or vehicle $(n=8)$ twice daily for 21 days. In mice receiving motesanib, hair regrowth was markedly depigmented compared with mice receiving vehicle (Figure 1). This effect was reversible. Following the cessation of motesanib treatment on day 21 , the mice were depilated again

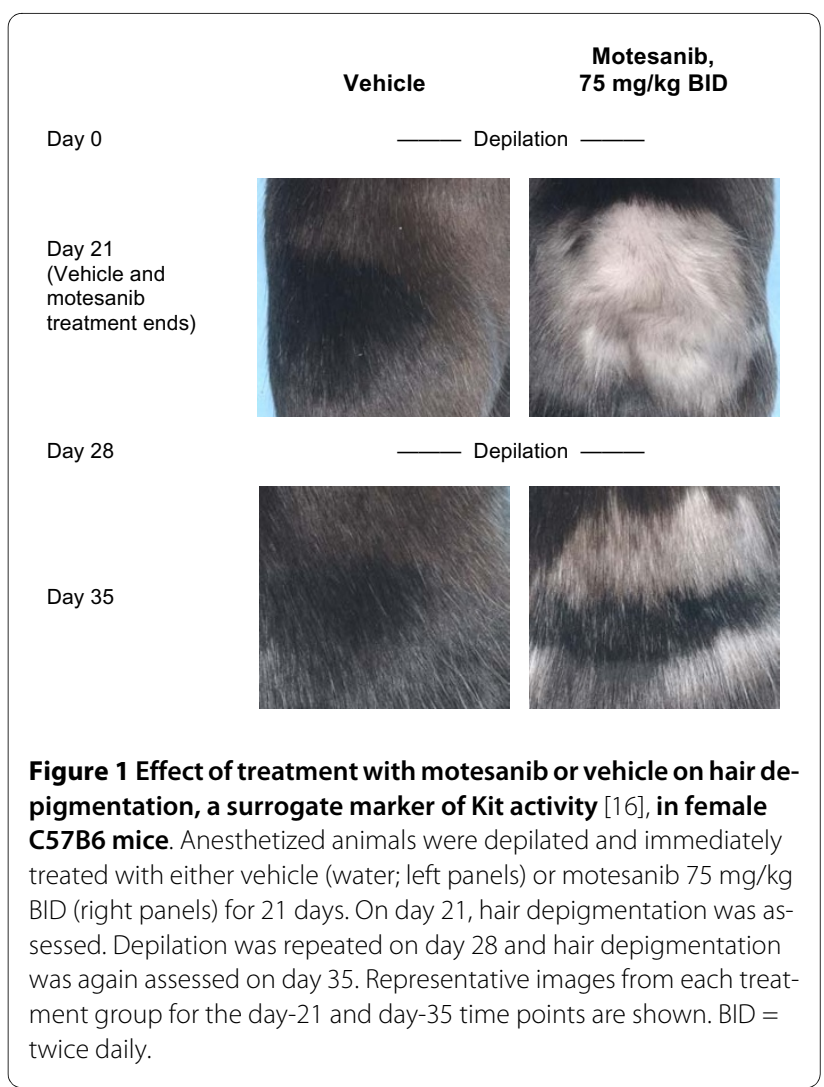


on day 28. There was no apparent depigmentation of regrown hair on day 35 . Similar results were obtained in male mice (data not shown).

\section{Characterization of Kit Mutants}

Figure 2 summarizes the results from the autophosphorylation experiments using $\mathrm{CHO}$ cells stably transfected with the wild-type KIT gene or various KIT mutant genes. Tyrosine phosphorylation of wild-type Kit was dose-dependent, with the greatest intensity of autophosphorylation occurring after a 30 minute incubation of the cells with $300 \mathrm{ng} / \mathrm{mL}$ of SCF. In contrast, tyrosine phosphorylation of activated Kit mutants occurred in the absence of SCF with no further phosphorylation induced by treatment with SCF.

\section{Activity of Motesanib against Primary Activating Kit Mutants}

In $\mathrm{CHO}$ cells, motesanib inhibited the autophosphorylation of the primary activating Kit mutants V560 D, $\Delta 552$ 559, and AYins503-504 (Table 2; Figure 3B). In each instance, motesanib was a more potent inhibitor of Kit autophosphorylation than imatinib. For example, motesanib inhibited the AYins503-504 mutant with an $\mathrm{IC}_{50}$ of $18 \mathrm{nM}$, whereas imatinib inhibited this mutant with an $\mathrm{IC}_{50}$ of $84 \mathrm{nM}$. Interestingly, the $\mathrm{IC}_{50}$ values for inhibition of these Kit mutants were lower than the $\mathrm{IC}_{50}$ for inhibition of wild-type Kit by motesanib. Consistent results were obtained in a functional viability assay utilizing IL3 -independent growth of Ba/F3 cells (Figure 3C). For example, when testing the AYins503-504 mutant, the $\mathrm{IC}_{50}$ for motesanib was $11 \mathrm{nM}$ versus $47 \mathrm{nM}$ for imatinib.

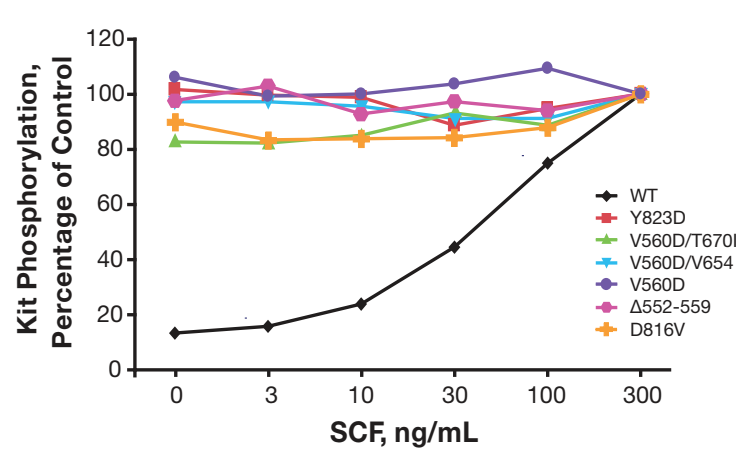

Figure 2 Effect of stem cell factor (SCF) treatment on tyrosine phosphorylation of wild-type Kit and mutant Kit isoforms stably expressed in Chinese hamster ovary cells. Chinese hamster ovary cells stably transfected with wild-type (WT) or mutant KIT isoforms were stimulated with single serial dilutions of stem cell factor, and Kit phosphorylation was assessed. For mutant Kit isoforms, data are expressed as the percentage of vehicle control. For wild-type Kit, data are expressed as the percentage of phosphorylation observed following stimulation with $300 \mathrm{ng} / \mathrm{mL}$ SCF. The results of a single experiment are shown.
Table 2: Inhibition of the Activity of Wild-Type Kit and Primary Activating Kit Mutants by Motesanib and Imatinib*

\begin{tabular}{|c|c|c|c|c|}
\hline \multirow[b]{2}{*}{ KIT Genotype } & \multicolumn{2}{|c|}{$\begin{array}{l}\mathrm{IC}_{50} \text { of Kit } \\
\text { Autophosphorylation, } \mathrm{nM}\end{array}$} & \multicolumn{2}{|c|}{$\begin{array}{l}\mathrm{IC}_{50} \text { of Stably } \\
\text { Transfected } \mathrm{Ba} / \mathrm{F3} \\
\text { Cell Survival, } \mathrm{nM}\end{array}$} \\
\hline & Motesanib & Imatinib & Motesanib & Imatinib \\
\hline Wild-type & 36 & 165 & - & - \\
\hline V560D & 5 & 18 & 3 & 7 \\
\hline$\Delta 552-559$ & 1 & 5 & 0.4 & 1 \\
\hline AYins503-504 & 18 & 84 & 11 & 47 \\
\hline
\end{tabular}

*In autophosphorylation experiments, means from 2 experiments are shown, with the exception of $\Delta 552-559$, which was assessed once. Viability experiments were performed once.

\section{Activity of Motesanib against Imatinib-Resistant Kit Mutants}

Motesanib inhibited the activity of Kit mutants associated with secondary imatinib resistance. In Kit autophosphorylation assays, motesanib inhibited tyrosine phosphorylation of the juxtamembrane domain/kinase domain I double mutants V560D/V654A and V560D/T670I with $\mathrm{IC}_{50}$ values of $77 \mathrm{nM}$ and $277 \mathrm{nM}$, respectively. Imatinib had limited activity against the V560D/V654A mutant and no activity against the V560D/T670I mutant at concentrations of up to $3000 \mathrm{nM}$ (Table 3; Figure 4B). Consistent results were obtained in the $\mathrm{Ba} / \mathrm{F} 3$ cells expressing the V560D/V654A and V560D/T670I mutants with motesanib $\mathrm{IC}_{50}$ values of $91 \mathrm{nM}$ and $180 \mathrm{nM}$, respectively. Again, motesanib was a more potent inhibitor of these mutants than imatinib (Table 3; Figure 4C).

Similarly, motesanib inhibited autophosphorylation of the imatinib-resistant activation loop mutant Y823 D $(\mathrm{IC} 50=64 \mathrm{nM})$ more potently than imatinib $(\mathrm{IC} 50>3000$ nM) (Table 3: Figure 4B). However, neither motesanib nor imatinib inhibited autophosphorylation of the D816V mutant (Table 3). Consistent with these results, motesanib inhibited the growth of $\mathrm{Ba} / \mathrm{F} 3$ cells transfected with the V560D/V654A, V560D/T670I, or Y823 D mutant more potently than imatinib. Of note, the IC50 of imatinib against the Y823 D mutant when established in the functional viability assay was at least 10-fold lower than the IC50 measured in the autophosphorylation assay. IL3-independent Ba/F3 cells expressing the D816V Kit mutant could not be established.

\section{Discussion}

In this study, motesanib was found to be a potent inhibitor of wild-type Kit, both in vitro and in vivo. In a surrogate marker assay, we observed reversible hair 


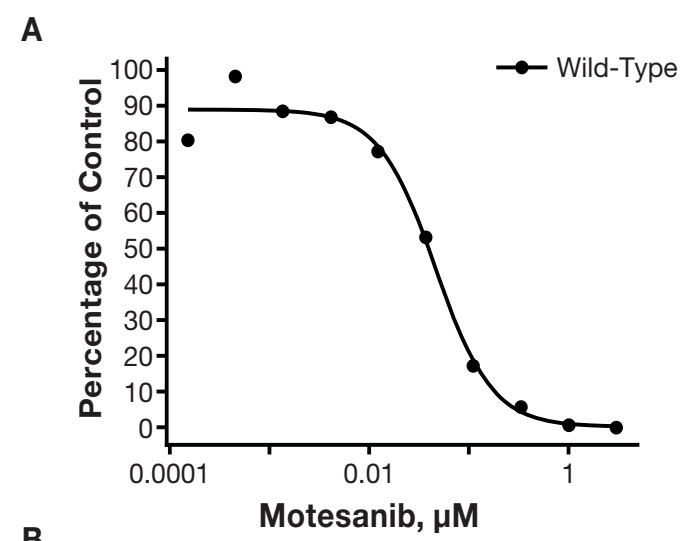

B

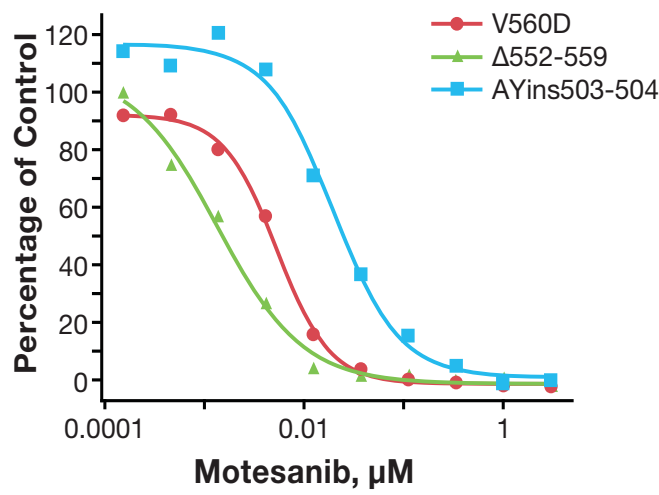

C

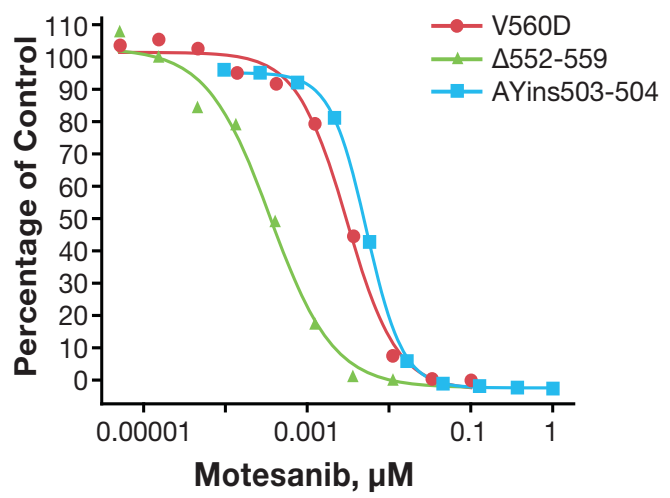

Figure 3 Inhibition of the activity of wild-type Kit and primary activating Kit mutants by motesanib. Autophosphorylation (expressed as a percentage of vehicle control) of wild-type Kit (panel A) and primary activating Kit mutants (panel B) was assessed in stably transfected Chinese hamster ovary cells treated for 2 hours with single 10-fold serial dilutions of motesanib. Representative data from 1 of 2 experiments are shown. Viability (expressed as the percentage of vehicle control) of $\mathrm{Ba} / \mathrm{F} 3$ cells expressing the same primary activating Kit mutants treated for 24 hours with single 10-fold serial dilutions of motesanib was also assessed (panel C). Viability experiments were performed once (representative curves are shown).

depigmentation in mice treated with motesanib $75 \mathrm{mg} / \mathrm{kg}$ twice daily. This dose is comparable to the doses used in xenograft studies demonstrating antitumor and antiangiogenic properties of motesanib $[9,17]$. Kit signaling plays an important role in the regulation of hair follicle
Table 3: Inhibition of the Activity of Kit Mutants Associated With Imatinib Resistance by Motesanib and Imatinib*

\begin{tabular}{lccccc}
\hline & \multicolumn{2}{l}{$\begin{array}{l}\text { IC }_{50} \text { of Kit } \\
\text { Autophosphorylation, } \mathbf{n M}\end{array}$} & $\begin{array}{l}\text { IC }{ }_{50} \text { of Stably } \\
\text { Transfected Ba/F3 } \\
\text { Cell Survival, } \mathbf{~ M ~}\end{array}$ \\
\cline { 2 - 3 } \cline { 5 - 6 } KIT Genotype & Motesanib & Imatinib & Motesanib & Imatinib \\
\hline V560D/V654A & 77 & 319 & & 91 & 145 \\
V560D/T670I & 277 & $>3000$ & & 180 & $>3000$ \\
Y823D & 64 & $>3000$ & 62 & 330 \\
D816V & $>3000$ & $>3000$ & - & -
\end{tabular}

*In autophosphorylation experiments, means from 2 experiments are shown, with the exception of V560D/V654A and D816V, which were assessed once. Viability experiments were performed once.

melanocytes, likely through control of tyrosinase and tyrosinase-related protein 1 (TRP1) expression [16]. Depigmentation has previously been observed in mice treated with anti-Kit antibodies $[16,18]$ or with sunitinib [18]. Importantly, motesanib had inhibitory activity against Kit mutants associated with GIST and inhibited these mutants more potently than imatinib and generally with an $\mathrm{IC}_{50}$ that was less than or similar to the 24-hour trough concentration of motesanib at therapeutic doses in humans [10].

Motesanib was a more potent inhibitor of the primary activating juxtamembrane domain and extracellular domain Kit mutants V560 D, $\Delta 552-559$, and AYins503504, compared with imatinib. Importantly, motesanib also inhibited the activity of an activation loop mutant (Y823D) associated with imatinib resistance. Imatinib did not inhibit this mutant at concentrations of up to 3000 $\mathrm{nM}$, suggesting that there are marked differences in how the two inhibitors interact with Kit. We previously solved the structure of motesanib bound to the VEGFR2 kinase domain at $2.2 \AA$ resolution (PDB Accession Code 3EFL) [19]. This structure superimposes favorably with that of Kit co-crystallized with imatinib (PDB Accession Code 1T46) [20]. Both inhibitors bind the inactive, auto-inhibited form of the kinases with the backbone of the protein reorganized into the so-called "DFG-out" conformation. Based on the structural similarities and the similar potencies of motesanib against VEGFR2 and Kit, we reasoned that motesanib binds these target kinases in exactly the same fashion.

Modeling studies suggest that motesanib engages Kit via three polar interactions and a multitude of van der Waals contacts (Figure 5). In the context of this study, the most important of these interactions are those with threonine 670 via a non-classical $\mathrm{CH}-\mathrm{O}$ pseudo hydrogen bond and interactions with valine 654 through hydropho- 
A
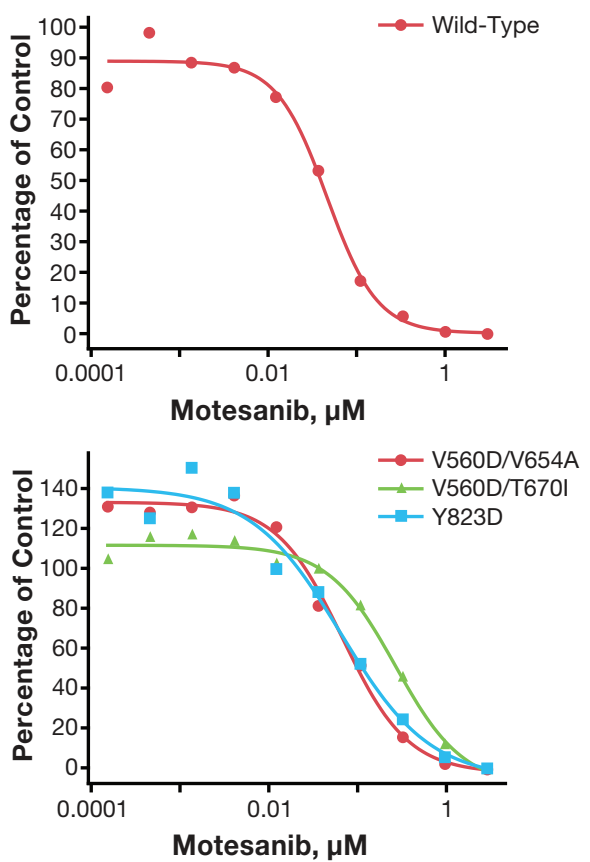

C

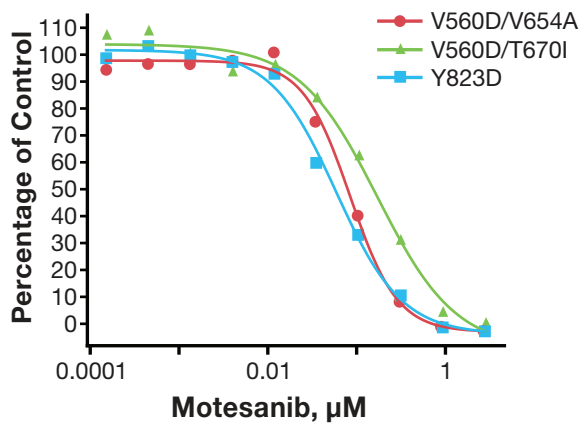

Figure 4 Inhibition of the activity of Kit mutants associated with secondary imatinib resistance by motesanib. Autophosphorylation (expressed as a percentage of vehicle control) of wild-type Kit (panel A) and Kit mutants associated with secondary imatinib resistance (panel B) was assessed in stably transfected Chinese hamster ovary cells treated for 2 hours with single 10 -fold serial dilutions of motesanib. Representative data from 1 of 2 experiments are shown. Viability (expressed as the percentage of vehicle control) of $\mathrm{Ba} / \mathrm{F} 3$ cells expressing the same Kit mutants treated for 24 hours with single 10 -fold serial dilutions of motesanib was also assessed (panel C; not shown: D816V, which had a motesanib $\left.I C_{50}>3 \mu \mathrm{M}\right)$. Viability experiments were performed once and representative curves are shown (D816V was not evaluated because Ba/F3 cells expressing this mutant could not be established).

bic contacts. The fifteen-fold loss of motesanib activity ( 5 $\mathrm{nM}$ versus $77 \mathrm{nM}$ ) noted with the V560D/V654A double mutant, compared with V560 D alone, is rationalized by the loss of two van der Waals contacts with alanine 654 in a similar fashion to that described for imatinib [21,22].

Motesanib and imatinib have much diminished activity against the activation loop mutant (D816V). The D816V

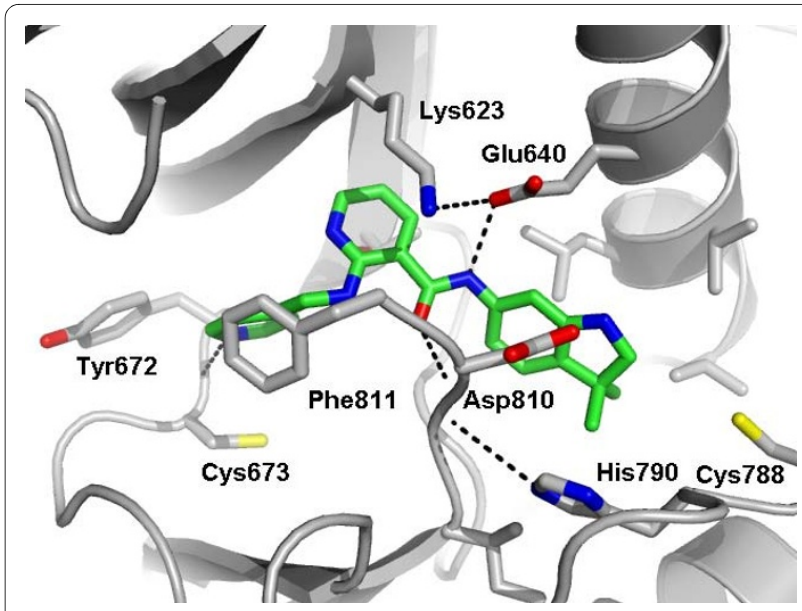

Figure $5 \mathrm{~A}$ model of motesanib bound to the active site of Kit kinase derived from a 2.2 Ångstrom resolution crystal structure of motesanib bound to the active site of VEGFR2 kinase (PDB code 2EFL).

mutant destabilizes the inactivated form of Kit, in a way that the ability of the protein to adopt the "DFG out" (inactive) conformation is much reduced or even eliminated; thus, the mutation prevents both motesanib and imatinib from binding to the ATP pocket [23,24]. The failure to potently inhibit the D816V mutation is a feature of Kit inhibitors in the clinic, with the exception for dasatinib $[23,25,26]$, which binds the "DFG in", or activated form, of the kinase [27]. However, the ability of motesanib to inhibit the Y823 D mutant suggests that its activity may not be entirely restricted to an inactive protein conformation, or alternatively it may reflect that in contrast to the $\mathrm{D} 816 \mathrm{~V}$ mutation, the conformational equilibrium of the Y823 D mutant is not shifted permanently to the active conformation.

The data from the present study are of translational relevance, supporting evidence indicating that targeted therapy molecules with different binding sites and/or mode of action may be required in the treatment of cancers for which mutations are the primary oncogenic event. A recent study has demonstrated that differences in the conformational structure of Kit mutants influences the ability of sunitinib [28], and imatinib to bind and inhibit receptor autophosphorylation, thus providing a unique mechanism of drug resistance for each mutant that is unlikely to be overcome using a single treatment [23].

\section{Conclusions}

In summary, the results of this study demonstrate that different Kit mutations respond differently to motesanib or imatinib. This likely reflects differences in the molecules' mode of action. The data also show that motesanib is active against Kit mutations associated with resistance, 
suggesting that it may have clinical utility in the treatment of patients with primary and secondary imatinibresistant GIST.

\section{Competing interests}

All authors are employees of and shareholders in Amgen Inc.

\section{Authors' contributions}

SC designed the cell viability and Kit autophosphorylation assays. LRG contributed to the generation of cell lines expressing wild-type and mutant Kit. AB performed the depilation experiments. TLB performed the depilation experiments. WB designed and generated wild-type and mutant KIT gene expression vectors. TJ designed and generated wild-type and mutant KIT gene expression vectors. RM contributed to the generation of cell lines expressing wild-type and mutant Kit. AST contributed the molecular modelling and assisted with the writing of the manuscript. AP was responsible for the overall experimental design and contributed to the writing of the manuscript. PEH was responsible for individual experimental designs and contributed to the writing of the mansucript. All authors have read and approved the final manuscript.

\section{Acknowledgements}

The authors wish to acknowledge Douglas Whittington and Joseph Kim (Amgen Inc., Cambridge, MA) for generating the model of motesanib bound to Kit. Additionally, the authors would like to thank Ali Hassan, PhD (Complete Healthcare Communications, Inc.), whose work was funded by Amgen Inc., and Beate Quednau, PhD (Amgen Inc.), for their assistance in the preparation of this manuscript.

\section{Author Details}

1Department of Oncology Research, Amgen Inc., One Amgen Center Drive, Thousand Oaks, CA, 91320-1799, USA, ${ }^{2}$ Department of Protein Science, Amgen Inc., One Amgen Center Drive, Thousand Oaks, CA, 91320-1799, USA, 3Department of Molecular Sciences, Amgen Inc., One Amgen Center Drive, Thousand Oaks, CA, 91320-1799, USA, ${ }^{4}$ Department of Medicinal Chemistry, Amgen Inc., One Amgen Center Drive, Thousand Oaks, CA, 91320-1799, USA and ${ }^{5}$ Department of Oncology, Amgen, Inc., 1201 Amgen Court West, Seattle, WA, 98119-3105, USA

Received: 30 March 2010 Accepted: 15 July 2010

Published: 15 July 2010

\section{References}

1. Heinrich MC, Corless CL, Demetri GD, Blanke CD, von Mehren M, Joensuu $H$, McGreevey LS, Chen CJ, Van den Abbeele AD, Druker BJ, Kiese B, Eisenberg B, Roberts PJ, Singer S, Fletcher CD, Silberman S, Dimitrijevic S, Fletcher JA: Kinase mutations and imatinib response in patients with metastatic gastrointestinal stromal tumor. J Clin Oncol 2003, 21:4342-4349

2. Hirota S, Isozaki K, Moriyama Y, Hashimoto K, Nishida T, Ishiguro S, Kawano K, Hanada M, Kurata A, Takeda M, Muhammad Tunio G, Matsuzawa Y, Kanakura Y, Shinomura Y, Kitamura Y: Gain-of-function mutations of ckit in human gastrointestinal stromal tumors. Science 1998, 279:577-580.

3. Corless CL, McGreevey L, Haley A, Town A, Heinrich MC: KIT mutations are common in incidental gastrointestinal stromal tumors one centimeter or less in size. Am J Pathol 2002, 160:1567-1572.

4. Corless CL, Fletcher JA, Heinrich MC: Biology of gastrointestinal stromal tumors. J Clin Oncol 2004, 22:3813-3825.

5. Heinrich MC, Corless CL, Duensing A, McGreevey L, Chen CJ, Joseph N, Singer S, Griffith DJ, Haley A, Town A, Demetri GD, Fletcher CD, Fletcher JA: PDGFRA activating mutations in gastrointestinal stromal tumors. Science 2003, 299:708-710

6. Demetri GD, von Mehren M, Blanke CD, Van den Abbeele AD, Eisenberg B, Roberts PJ, Heinrich MC, Tuveson DA, Singer S, Janicek M, Fletcher JA, Silverman SG, Silberman SL, Capdeville R, Kiese B, Peng B, Dimitrijevic S, Druker BJ, Corless C, Fletcher CD, Joensuu H: Efficacy and safety of imatinib mesylate in advanced gastrointestinal stromal tumors. NEngl J Med 2002, 347:472-480.

7. Frost MJ, Ferrao PT, Hughes TP, Ashman LK: Juxtamembrane mutant V560GKit is more sensitive to Imatinib (STI571) compared with wild- type c-kit whereas the kinase domain mutant D816VKit is resistant. Mol Cancer Ther 2002, 1:1115-1124.

8. Heinrich MC, Corless CL, Blanke CD, Demetri GD, Joensuu H, Roberts PJ, Eisenberg BL, von Mehren M, Fletcher CD, Sandau K, McDougall K, Ou WB, Chen CJ, Fletcher JA: Molecular correlates of imatinib resistance in gastrointestinal stromal tumors. J Clin Oncol 2006, 24:4764-4774.

9. Polverino A, Coxon A, Starnes C, Diaz Z, DeMelfi T, Wang L, Bready J, Estrada J, Cattley R, Kaufman S, Chen D, Gan Y, Kumar G, Meyer J, Neervannan S, Alva G, Talvenheimo J, Montestruque S, Tasker A, Patel V, Radinsky R, Kendall R: AMG 706, an oral, multikinase inhibitor that selectively targets vascular endothelial growth factor, platelet-derived growth factor, and kit receptors, potently inhibits angiogenesis and induces regression in tumor xenografts. Cancer Res 2006, 66:8715-8721.

10. Rosen LS, Kurzrock R, Mulay M, Van Vugt A, Purdom M, Ng C, Silverman J, Koutsoukos A, Sun YN, Bass MB, Xu RY, Polverino A, Wiezorek JS, Chang DD, Benjamin R, Herbst RS: Safety, pharmacokinetics, and efficacy of AMG 706, an oral multikinase inhibitor, in patients with advanced solid tumors. J Clin Oncol 2007, 25:2369-2376.

11. Price TJ, Lipton L, McGreivy J, McCoy S, Sun YN, Rosenthal MA: Safety and pharmacokinetics of motesanib in combination with gemcitabine for the treatment of patients with solid tumours. Br J Cancer 2008, 99:1387-1394

12. Schlumberger MJ, Elisei R, Bastholt L, Wirth LJ, Martins RG, Locati LD, Jarzab B, Pacini F, Daumerie C, Droz JP, Eschenberg MJ, Sun YN, Juan T, Stepan DE, Sherman SI: Phase II study of safety and efficacy of motesanib in patients with progressive or symptomatic, advanced or metastatic medullary thyroid cancer. J Clin Oncol 2009, 27:3794-3801.

13. Sherman SI, Wirth $\sqcup$, Droz JP, Hofmann M, Bastholt L, Martins RG, Licitra L, Eschenberg MJ, Sun YN, Juan T, Stepan DE, Schlumberger MJ: Motesanib diphosphate in progressive differentiated thyroid cancer. N Eng/ J Med 2008, 359:31-42.

14. Benjamin R, Schöffski P, Hartmann JT, Bui BN, Duyster J, Schuetze S, Blay J, Reichard P, Rosen L, Skubitz K, Eschenberg M, Stepan D, Baker L: Initial results of a multicenter single arm phase 2 study of $A M G$ 706, an oral multi-kinase inhibitor, for the treatment of advanced imatinib-resistant gastrointestinal stromal tumors (GIST) [abstract 641]. Connective Tissue Oncology Society 12th Annual Meeting 2006. Venice, Italy. Year

15. Sawaki A, Yamada Y, Komatsu Y, Kanda T, Doi T, Koseki M, Baba H, Sun YN, Murakami K, Nishida T: Phase II study of motesanib in Japanese patients with advanced gastrointestinal stromal tumors with prior exposure to imatinib mesylate. Cancer Chemother Pharmacol 2009, 65:961-967.

16. Botchkareva NV, Khlgatian M, Longley BJ, Botchkarev VA, Gilchrest BA: $\mathrm{SCF} / \mathrm{c}$-kit signaling is required for cyclic regeneration of the hair pigmentation unit. FASEB J 2001, 15:645-658.

17. Coxon A, Bush T, Saffran D, Kaufman S, Belmontes B, Rex K, Hughes P, Caenepeel S, Rottman JB, Tasker A, Patel V, Kendall R, Radinsky R, Polverino A: Broad antitumor activity in breast cancer xenografts by motesanib, a highly selective, oral inhibitor of vascular endothelial growth factor, platelet-derived growth factor, and Kit receptors. Clin Cancer Res 2009, 15:110-118

18. Moss KG, Toner GC, Cherrington JM, Mendel DB, Laird AD: Hair depigmentation is a biological readout for pharmacological inhibition of KIT in mice and humans. J Pharmacol Exp Ther 2003, 307:476-480.

19. Tasker AS, Patel VF: Discovery of motesanib. In Kinase Inhibitor Drugs Edited by: Li R, Stafford JA. Hoboken, NJ: John Wiley \& Sons, Inc.; 2009:113-130

20. Mol CD, Dougan DR, Schneider TR, Skene RJ, Kraus ML, Scheibe DN, Snell GP, Zou H, Sang BC, Wilson KP: Structural basis for the autoinhibition and STI-571 inhibition of c-Kit tyrosine kinase. J Biol Chem 2004, 279:31655-31663.

21. McLean SR, Gana-Weisz M, Hartzoulakis B, Frow R, Whelan J, Selwood D, Boshoff C: Imatinib binding and CKIT inhibition is abrogated by the CKIT kinase domain I missense mutation Val654Ala. Mol Cancer Ther 2005, 4:2008-2015.

22. Roberts KG, Odell AF, Byrnes EM, Baleato RM, Griffith R, Lyons AB, Ashman LK: Resistance to c-KIT kinase inhibitors conferred by V654A mutation. Mol Cancer Ther 2007, 6:1159-1166.

23. Gajiwala KS, Wu JC, Christensen J, Deshmukh GD, DiehI W, Dinitto JP, English JM, Greig MJ, He YA, Jacques SL, Lunney EA, McTigue M, Molina D, Quenzer T, Wells PA, Yu X, Zhang Y, Zou A, Emmett MR, Marshall AG, Zhang HM, Demetri GD: KIT kinase mutants show unique mechanisms 
of drug resistance to imatinib and sunitinib in gastrointestinal stromal tumor patients. Proc Natl Acad Sci USA 2009, 106:1542-1547.

24. Foster R, Griffith R, Ferrao P, Ashman L: Molecular basis of the constitutive activity and STI571 resistance of Asp816Val mutant KIT receptor tyrosine kinase. J Mol Graph Model 2004, 23:139-152.

25. Schittenhelm MM, Shiraga S, Schroeder A, Corbin AS, Griffith D, Lee FY, Bokemeyer C, Deininger MW, Druker BJ, Heinrich MC: Dasatinib (BMS354825), a dual SRC/ABL kinase inhibitor, inhibits the kinase activity of wild-type, juxtamembrane, and activation loop mutant KIT isoforms associated with human malignancies. Cancer Res 2006, 66:473-481.

26. Shah NP, Lee FY, Luo R, Jiang Y, Donker M, Akin C: Dasatinib (BMS354825) inhibits KITD816V, an imatinib-resistant activating mutation that triggers neoplastic growth in most patients with systemic mastocytosis. Blood 2006, 108:286-291.

27. Tokarski JS, Newitt JA, Chang CY, Cheng JD, Wittekind M, Kiefer SE, Kish K, Lee FY, Borzillerri R, Lombardo LJ, Xie D, Zhang Y, Klei HE: The structure of Dasatinib (BMS-354825) bound to activated ABL kinase domain elucidates its inhibitory activity against imatinib-resistant $A B L$ mutants. Cancer Res 2006, 66:5790-5797.

28. Demetri GD, van Oosterom AT, Garrett CR, Blackstein ME, Shah MH, Verweij J, MCArthur G, Judson IR, Heinrich MC, Morgan JA, Desai J, Fletcher CD, George S, Bello CL, Huang X, Baum CM, Casali PG: Efficacy and safety of sunitinib in patients with advanced gastrointestinal stromal tumour after failure of imatinib: a randomised controlled trial. Lancet 2006, 368:1329-1338

doi: 10.1186/1756-9966-29-96

Cite this article as: Caenepeel et al., Motesanib inhibits Kit mutations associated with gastrointestinal stromal tumors Journal of Experimental \& Clinical Cancer Research 2010, 29:96

Submit your next manuscript to BioMed Centra and take full advantage of:

- Convenient online submission

- Thorough peer review

- No space constraints or color figure charges

- Immediate publication on acceptance

- Inclusion in PubMed, CAS, Scopus and Google Scholar

- Research which is freely available for redistribution

Submit your manuscript at www.biomedcentral.com/submit
Biomed Central 